\title{
酸ーアセトン法によって調製されたグロビンならびに グロビン加水分解物のゲル形成性
}

\author{
劉 新旗*・米倉政実*・堤 将和* \\ Gel Formation of Globin Prepared by Acid-acetone \\ Method and Globin Hydrolyzates \\ Shinki RYu*, Masami YonekURA* and Masakazu Tsutsumi* \\ * Faculty of Agriculture, Ibaraki University, 3-21-1, \\ Amimachi-chuo, Inashikigun, Ibaraki 300-03
}

The gel formation of porcine globin prepared by the acid-acetone method and the acid hydrolyzates of the resulting globin were investigated. (1) Globin dissolved in acidic solution below

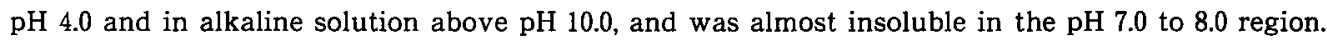
(2) Globin gel was formed in the $\mathrm{pH}$ range $2.0 \sim 4.0$ and $10.0 \sim 11.0$, and at a globin concentration above 7\%. (3) Though globin formed the gel when citric acid was added in the range of $0.02 \mathrm{M}$ to $0.2 \mathrm{M}$, the further addition of the acid, $0.4 \mathrm{M}$ to $2.0 \mathrm{M}$, inhibited the gel formation. However, the transparent gel was formed when the solutions whose gel formation was inhibited were allowed to stand at $30^{\circ} \mathrm{C}$ for 10 days. In the case of acetic acid and phosphoric acid, the effects of these acids on gel formation was similar to that of citric acid though acid concentration and the values of gel strength of the gel formed were different from those of citric acid, respectively. The hydrolysis of globin in these acids and SDS -PAGE of the resulting hydrolyzates were carried out. When the hydrolysis was done by these concentrated acids, the protein band of about $15 \mathrm{kDa}$ which is thought to be globin was pale and the bands below $15 \mathrm{kDa}$, on the contrary, were dark. From the results, it is thought that the hydrolyzates produce a marked effect on the gel formation of globin. In addition, it was suggested that the proportion of globin to the hydrolyzates was closely correlated with the gel strength of the gel formed.

(Received July 5, 1993)

グロビンは，と畜血液の血球画分から容易に，かつ大 量に得ることができるタンパク質であるが, 特に優れた 加工特性が見い出されないために，ほとんど利用されて いないのが実情である.そこで著者らは，グロビンの有 効利用を目指して本研究を行った．特にグロビンのゲル 形成性に着目し，ゲル形成条件ならびにゲル特性につい て研究を行った。

まず，豚血液の血球画分からグロビンを調製する方法 として，過酸化水素法1)，カルボキシルメチルセルロー ス (CMC) 法2)などの方法が報告されているが，本報告 では，調製法が簡便で，特別な装置を必要とせず，かつ 大量処理が可能な酸ーアセトン法3)によってグロビンを
調製し, 得られたグロビンのゲル形成性について検討し た. 従来, 本法で調製されたグロビンはゲルを形成しに くいと言われていだ)が，本報に述べられたように，本 グロビンむ，ある条件下で強いゲルを形成することを明 らかにした，しかし，このグロビンゲルは不透明ゲルで あるため, 食品加工材料として若干問題が残った，そこ で著者らはこの点を解決するため，酸によるグロビンの 部分加水分解を行ったところ，ょり透明で高いゲル強度 を示すゲルが形成された，本報告はこれらの結果をまと めたあのである。

\footnotetext{
* 茨城大学農学部（元300-03 茨城県稲敷郡阿見町中央 3-21-1）
} 


\section{実 験 方 法}

\section{1. グロビンの調製}

グロビンは TYBOR らの酸-アセトン法"5) 一部改変し て調製しだ)。

\section{2. グロビンの溶解性}

各 $\mathrm{pH}$ の緩衝液 (pH 2.0 7.0 は McIlvain 緩衝液, $\mathrm{pH} 8.0 \sim 11.0$ は Atkins \& Pantine 緩衛液) $4 \mathrm{ml}$ にグロ ビン $4 \mathrm{mg}$ を加えてよく摜汼した後， $5^{\circ} \mathrm{C} て ゙ 1$ 日放置し た. その後これらを遠心分離 $(3000 \times \mathrm{g} ， 15$ 分) し, 得 られた上清のタンパク質量を色素結合法6)で定量した。

3. グロビンゲルの調製と透明度，ゲル強度の測定

グロピンゲルは，指定濃度のグロビンを，塩酸と水酸 化ナトリウムで $\mathrm{pH}$ 1.0 11.0 に調整した後シリコン栓 で封じ， $90^{\circ} \mathrm{C} ， 15$ 分，オートクレーブで加熱した後，室 温で 60 分以上放置して調製した(このゲルを“加熱直後 のゲル゙と略す). ゲルを形成しているものについては， 光電比色計を用いて $700 \mathrm{~nm}$ の透過率 (T\%) を測定し， ゲルの透明度を，0〜39 T\%は不透明，40６9 T\% は半 透明，70〜100 T\%は透明として表した。 グロビンのゲ ル形成に対する酸類の影罩を検討するために，次のよう な実験を行った．まず， $7 \%$ グロビン液に指定漂度にな るように酸を添加して $\mathrm{pH}$ を測定した後，上記の条件で 加熱した．ゲルを形成したすのについては，透明度とゲ ル強度を測定した．ゲルを形成しないものについては， そのまま $30^{\circ} \mathrm{C} て ゙ ~ 10$ 日間放置し，この時点でゲルを形成 したあのについては，同様に透明度とゲル強度を測定し た. ゲル強度は前報7に準じ，レオメーター(NRM 2003 J型，不動工業）を用いて 3 回以上湘定しレオプロッ ター (FR 801 型, 不動工業) による演算値の平均値で示 した。なお，本報告ではゲル強度を破断応力（Breaking stress）で示した.

\section{4. 電気泳動}

LAEMMLI の方法影に従って SDS-ポリアクリルアミド ゲル電気泳動 (SDS-PAGE) を行った。ポリアクリルア ミドの濃度を $15 \%$ とし，クーマシーブリリアントブ ルーR-250で染色した。装置はマイクロスラブ電気泳動 装置（KS-8010 MARYSOL）を用いた。

\section{実 跧 結 果}

\section{1、グロビンの溶解性}

各 $\mathrm{pH}$ でのグロビンの溶解性を検討し，その結果を Fig. 1 に示した.

グロビンの溶解性は $\mathrm{pH} 4.0$ 以下の酸性域で高く, $\mathrm{pH}$

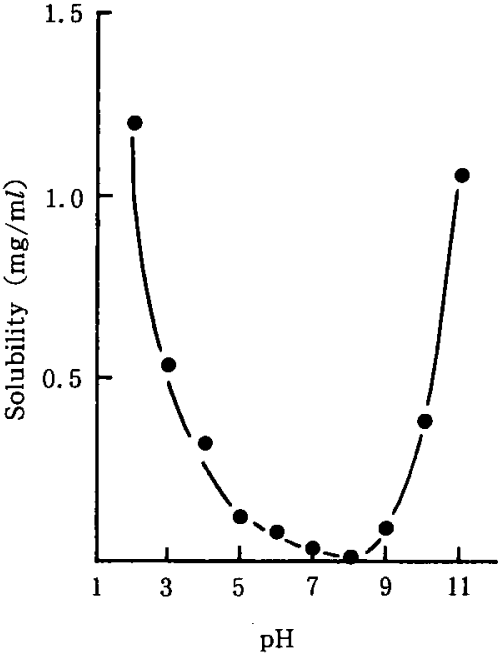

Fig. 1 Effect of $\mathrm{pH}$ on solubility of globin

$5.0 \sim 9.0$ の範囲で低く, $\mathrm{pH} 7.0 \sim 8.0$ で最低值となった. このことはグロビンの等電点 $(\mathrm{pH} 7.6 \sim 7.8)$ を考える と，妥当な結果と言える。なお，多くの食品タンパク質 と同様に, グロビンも $\mathrm{pH} 10.0$ 以上の $\mathrm{pH}$ 域ではよく溶 解した。

2. グロビンのゲル形成性に対するグロビン濃度と pH の影響

グロビンのゲル形成性に対するグロビン濃度と $\mathrm{pH}$ の影響について検討し，その結果を Table 1 に示した。

Table 1 から明らかなように，グロビンは 5\%以下の 濃度でゲルを形成しなかったが，7\% 以上の溧度でゲル を形成した．また，グロビンは $\mathrm{pH} 2.0 \sim 4.0$ (塩酸による 調整）の酸性域，および $\mathrm{pH} 10.0 \sim 11.0$ (水酸化ナトリウ ムによる調整)のアルカリ性域でゲルを形成した。なお， $\mathrm{pH} 11.0$ では透明なゲルを, $\mathrm{pH}$ 2.0 3.0では半透明なゲ ルを形成したが， $\mathrm{pH} 4.0$ と $\mathrm{pH} 10.0$ では不透明ゲルで あった．ゲル強度は $\mathrm{pH} 10.0$ で最す高い值を示し，酸性 域では $\mathrm{pH} 3.0$ で高いゲル強度を示した。

3. グロビンのゲル形成性に対する酸類の影習

グロビンのゲル形成性に対するクエン酸, 酢酸, リン 酸の影響について検討し，その結果を Table 2，Table 3, Table 4 に示した.

まず，クエン酸の場合（Table 2)，添加濃度が $0.2 \mathrm{M}$ （pH 2.6）までゲルを形成し，0.4 M（pH 2.2）以上になる とゲルを形成しなかった．形成したゲルのゲル強度は， クエン酸の添加濃度が高くなるにしたがって弱くなっ た、ゲルの透明度はクェン酸の添加濃度が高くなるほど 
Table 1 Gel properties of globin

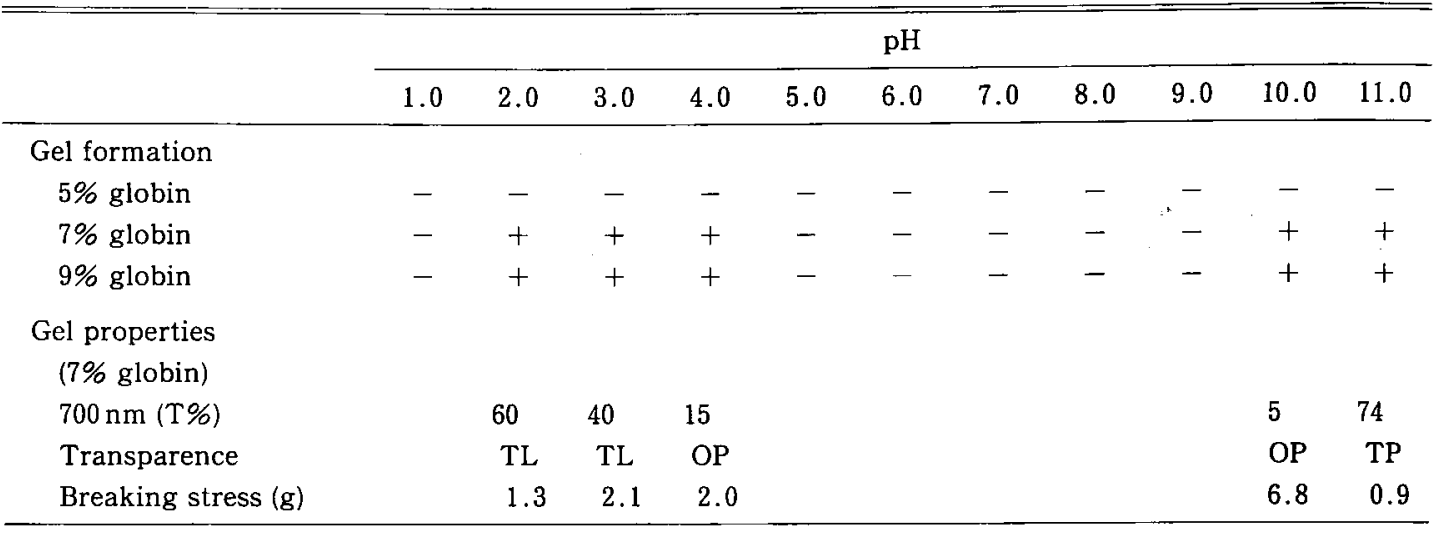

+ : Gel was formed. - : Gel was not formed.

Transparence : OP, Opaque TL, Translucent TP, Transparent

Table 2 Effect of citric acid on the gel strength of globin gel

\begin{tabular}{|c|c|c|c|c|c|c|c|c|c|c|c|}
\hline & \multicolumn{11}{|c|}{ Citric acid concentration (M) } \\
\hline & 0.02 & 0.04 & 0.06 & 0.08 & 0.1 & 0.2 & 0.4 & 0.8 & 1.4 & 2.0 & 2.4 \\
\hline $\mathrm{pH}$ & 3.6 & 3.2 & 3.0 & 3.0 & 2.9 & 2.6 & 2.2 & 1.9 & 1.6 & 1.3 & 1.1 \\
\hline $700 \mathrm{~nm}(\mathrm{~T} \%)$ & 37 & 47 & 58 & 60 & 65 & 80 & 84 & 85 & 88 & 93 & 94 \\
\hline $\begin{array}{l}\text { Transparence }{ }^{1)} \\
\text { Breaking stress (g) }\end{array}$ & OP & TL & $\mathrm{TL}$ & $\mathrm{TL}$ & $\mathrm{TL}$ & $\mathrm{TP}$ & TP & $\mathrm{TP}$ & $\mathrm{TP}$ & $\mathrm{TP}$ & $\mathrm{TP}$ \\
\hline after heating-cooling ${ }^{2)}$ & 4.0 & 1.9 & 1.8 & 1.7 & 1.6 & 1.0 & - & - & - & - & 一 \\
\hline after 10 days $^{3)}$ & 7.0 & 5.0 & 3.3 & 3.0 & 3.6 & 6.8 & 9.5 & 20.0 & 16.0 & 8.8 & - \\
\hline
\end{tabular}

1) See Table 1.

2) The gel was formed immediately after heating-cooling.

3) The gel was formed after allowing to stand at $30^{\circ} \mathrm{C}$ for 10 days.

Table 3 Effect of acetic acid on the gel strength of globin gel

\begin{tabular}{lcccccccccc}
\hline & \multicolumn{10}{c}{ Acetic acid concentration (M) } \\
\cline { 2 - 11 } & 0.02 & 0.04 & 0.06 & 0.08 & 0.1 & 0.2 & 0.4 & 0.8 & 1.4 \\
\hline $\mathrm{pH}$ & 4.3 & 4.1 & 4.0 & 3.9 & 3.9 & 3.7 & 3.5 & 3.2 & 3.0 \\
$700 \mathrm{~nm}(\mathrm{~T} \%)$ & 31 & 37 & 40 & 42 & 43 & 66 & 70 & 70 & 71 \\
Transparence & OP & OP & TL & TL & TL & TL & TP & TP & TP \\
Breaking stress (g) & & & & & & & & & \\
$\quad$ after heating-cooling & 2.8 & 4.5 & 4.2 & 4.0 & 3.5 & - & - & - & - \\
$\quad$ after 10 days & 7.5 & 9.5 & 9.7 & 9.4 & 7.7 & 3.5 & 2.0 & 7.5 & 25.0 \\
\hline
\end{tabular}

Abbreviations etc. : See Table 2.

高くなる傾向を示した．なお，形成された加熱直後のゲ ルを， $30^{\circ} \mathrm{C}$ で 10 日間放置したところ，ゲル強度が全体 的に上昇した。一方，クエン酸の添加濃度が $0.4 \mathrm{M}$ 以上 になると，加熱直後では，ゲルの形成が認められなかっ たが，これらを $30^{\circ} \mathrm{C}$ で 10 日間放置したところ，より透 明で高いゲル強度を示すゲルが形成された．すなわち，
クエン酸の添加濃度 $0.2 \mathrm{M}$ から急激にゲル強度が高くな り， $0.8 \mathrm{M}(\mathrm{pH} \mathrm{1.9)}$ で最大值を示した. しかし，クエン 酸の添加濃度がこれ以上高くなると，ゲル強度は徐々に 低下する傾向を示し, $2.4 \mathrm{M}(\mathrm{pH}$ 1.1) 添加でゲルの形成 は完全に阻害された。 また，クエン酸の添加濃度が高く なるにしたがって，ゲルの透明度も上昇し， $0.2 \mathrm{M}$ 以上 
Table 4 Effect of phosphoric acid on the gel strength of globin gel

\begin{tabular}{lccccccccc}
\hline \hline & \multicolumn{8}{c}{ Phosphoric acid concentration (M) } \\
\cline { 2 - 10 } & 0.02 & 0.04 & 0.06 & 0.08 & 0.1 & 0.2 & 0.4 & 0.8 \\
\hline $\mathrm{pH}$ & 3.2 & 2.6 & 2.2 & 2.1 & 2.0 & 1.7 & 1.3 & 1.1 \\
$700 \mathrm{~nm}$ (T\%) & 45 & 70 & 70 & 74 & 80 & 84 & 90 & 97 \\
Transparence & $\mathrm{TL}$ & $\mathrm{TP}$ & $\mathrm{TP}$ & $\mathrm{TP}$ & $\mathrm{TP}$ & $\mathrm{TP}$ & $\mathrm{TP}$ & $\mathrm{TP}$ \\
Breaking stress (g) & & & & & & & & \\
after heating-cooling & 1.0 & 0.7 & - & - & - & - & - & - \\
after 10 days & 1.7 & 1.9 & 3.5 & 5.5 & 5.5 & 5.0 & 1.0 & - \\
\hline
\end{tabular}

Abbreviations etc. : See Table 2.

添加すると透明ゲルが形成された。

酢酸の場合（Table 3)，酢酸の添加濃度が $0.1 \mathrm{M}(\mathrm{pH}$ 3.9）までゲルの形成が認められた。ゲル強度は $0.04 \mathrm{M}$ (pH 4.1) 添加で最大値を示し，それ以上の濃度では徐々 に低下し，0.2 M (pH 3.7) 添加でゲル形成は完全に阻害 された．ゲルの透明度は酷酸の添加浱度が高くなるにし たがって高くなる傾向を示した，なお，加熱直後のゲル を，30ㄷ 同様，全体的にゲル強度が上昇し，また $0.2 \mathrm{M}$ 酢酸添加 のものも透明なゲルを形成した．特に酢酸の場合は，添 加漂度が $0.8 \mathrm{M}$ 以上からゲル強度は高くなる㑯向を示 し，1.4M（pH 3.1）添加まではほぼ直線的に上昇した。 今回はこれ以上の濃度で実験を行っていないので, 最大 のゲル強度を示す酢酸添加量を求めることはできなかっ た.

リン酸添加の影響（Table 4）は，ゲルの形成性ならび にゲル強度に影響する濃度の違いはあるものの, クエン 酸添加の場合と同じょうな傾向であった.

\section{4. グロビン酸加水分解物の電気泳動}

グロビンにクエン酸などの酸を添加して，ゲル形成に 対するこれらの酸の影響を検討したところ，興味ある現 象が見いだされた (Table 2〜Table 4).この場合，原因 の一つとしてグロビンの酸による加水分解が考えられ

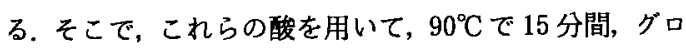
ビンの酸加水分解を行い, 得られた加水分解物の電気泳 動を行った. その結果を Fig. 2，Fig. 3，Fig. 4 に示し た.

まず，クエン酸によるグロビン加水分解物の電気泳動 図をFig. 2 に示した，Fig. 2 から明らかなように，クエ ン酸の濃度が高くなるにしたがって，グロビンに相当す るバンド部分 $(15 \mathrm{kDa})$ が薄くなり，逆に加水分解物に 相当するパンドの部分 ( $15 \mathrm{kDa}$ 以下) が濃くなった. 酢 酸の場合は，濃度が高くなっても $\mathrm{pH}$ がそれ程低下しな
いため（Table 3) 加水分解力む弱く，結果的に $15 \mathrm{kDa}$ の部分はそれ程薄くならず，また $15 \mathrm{kDa}$ 以下の部分す クエン酸の場合程濃くはならなかった（Fig. 3).リン酸 の場合, 加水分解力はクエン酸よりも強力であったが, リン酸の漂度と加水分解物の生成量との関係は，クエン 酸の場合と同じような傾向を示した（Fig. 4).

$$
\text { 考察 }
$$

食品加工においてタンパク質は，栄養素としてのみな らず，食品に固有な構造や物性を与える要素として，大 きな役割を担っている. 本研究で用いられたグロビン も, 一栄養学的には必須アミノ酸 (バリン, ロイシン, リ ジンなど）が多く，食材として注目されてはいるものの， 加工特性に関する研究が少ないため，その利用は殆ど進 展していないのが実情である。そこで著者らは，グロビ ンの加工特性, 特にグロビンのゲル形成性に着目して, 本研究を行った.

グロビンのゲル形成性は，グロビンの調製法の違いに より異なる ${ }^{9)}$. 例えば，CMC 法で調製されたグロビン は，ゲルを形成すると言われているが，本法で調製され たグロビンは，ゲルを形成しにくいと言われてきだ). 従って著者らは，まずグロビンのゲル形成性について詳 細に検討した，その結果，グロビンのゲル形成はグロビ ン浱度と $\mathrm{pH}$ に強く依存することが明らかとなった (Table 1).すなわち, ゲルの形成には $7 \%$ 以上のグロビ ン濃度を必要とすることがわかった。この点は，代表的 なタンパク質系のゲル化浏であるゼラチンのゲル形成裖 度（通常 4 5\%で十分ゲルを形成する）に比べてす，高 い濃度である. 従って，本グロビンを食品加工における ゲル化倣として使用する場合, 高濃度グロビンによる好 ましくない風味の付与等も考えられる．今後より低濃度 でゲルを形成するようグロビンを改变することが重要な 課題である. 

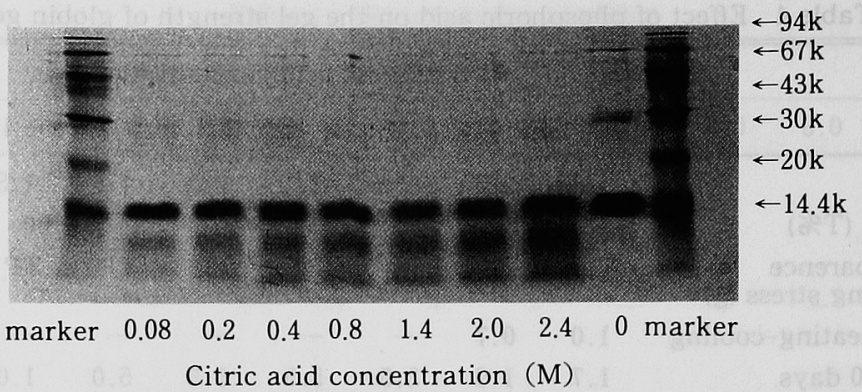

Fig. 2 SDS-PAGE patterns of globin hydrolyzates by citric acid

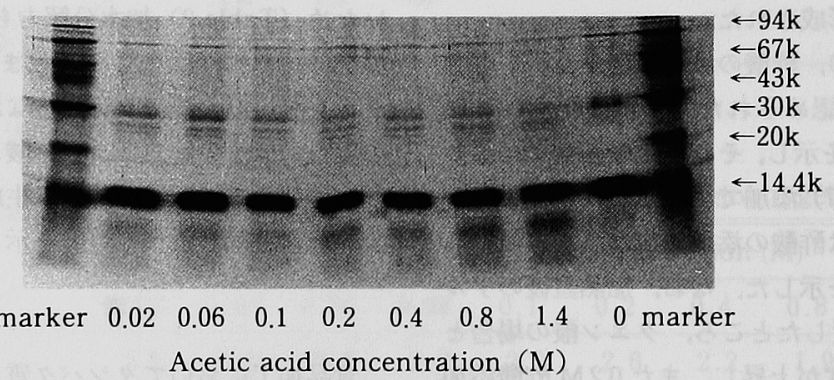

Fig. 3 SDS-PAGE patterns of globin hydrolyzates by acetic acid

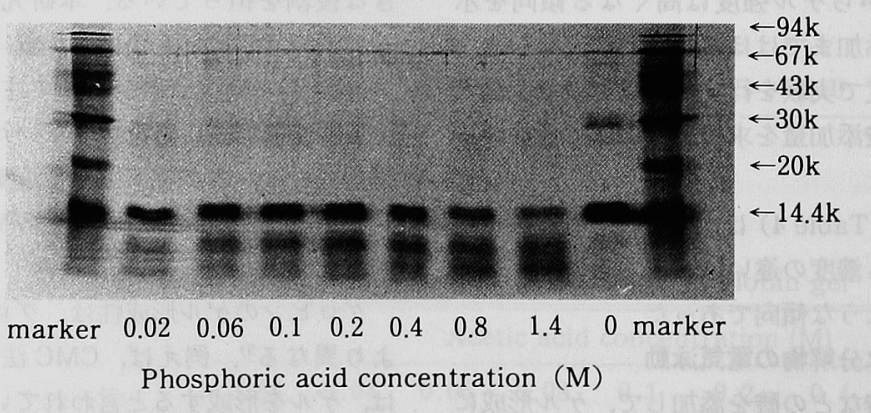

Fig. 4 SDS-PAGE patterns of globin hydrolyzates by phosphoric acid

グロビンのゲル形成は $\mathrm{pH}$ の影響を受けた．すなわ ち,グロビンの等電点付近（pH 7.6 7.8）加らより離れ た $\mathrm{pH}$ でゲルを形成した．等電点から離れた $\mathrm{pH}$ 域で は，グロビンの分子間の眯水結合や水素結合は，静電的 反発力より大きくなるので, 分子間の凝集力す強くな り，結果的に巨大な凝集体を生じ，ゲルを形成しやすく

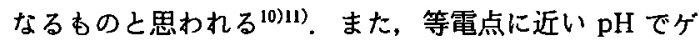

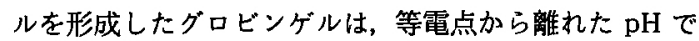
形成したゲルに比へ，不透明であった。このことは,グ ロビンの溶解性（Fig. 1）之関連しているものと思われ る.つまり，等電点に近い $\mathrm{pH}$ では，不溶性のグロビン
粒子が網目構造の中により多く分散しているため，透明 度が低くなるものと思われる ${ }^{12)}$.

グロビンのゲル形成に対するクェン酸，酢酸，リン酸 の影響を検討したところ，興味ある現象が見いだされた (Table 2〜Table 4). 特に, 加熱直後にゲルを形成しな かった濃度範井のものを， $30^{\circ} \mathrm{C}$ で 10 日間放置したとこ ろ, 加熱直後のゲルよりあ透明で，高いゲル強度を示す ゲルが形成された．この現象は，これらの酸によるグロ ビンの部分的加水分解によるものと考えられた。 そこ で, この点を明らかにするために, 酸加水分解物の電気 泳動を行った (Fig. 2〜Fig. 4). 電気泳動の結果, 本法で 
調製されたグロビンは， $15 \mathrm{kDa}$ 付近に濃いバンドが認 められ，これはグロビンの $\alpha$-鎖之 $\beta$-鎖の単量体（いず れる分子量は約 $16 \mathrm{kDa}$ ) 之推定された。 なお，このバン ドはより濃い酸の添加によって徐々に薄くなり，同時に $15 \mathrm{kDa}$ 以下のバンドが徐々に濃くなった。このことは， グロビンが酸によって加水分解を受け，より低分子化し たことを示す。しかし，酸の添加量が多くなると，グロ ビンの分解が進み，低分子部分が相対的に過剩になる上 同時に, $\mathrm{pH}$ あ 1.0 近くになり,ゲルの形成は逆に阻害さ れた (Table 2 と Fig. 2, Table 4 と Fig. 4). すなわち, 酸加水分解物によるゲルの形成には, 約 $15 \mathrm{kDa}$ のポリ ペプチドと $15 \mathrm{kDa}$ 以下のポリペプチドの適当な量比が 重要であると思われる.

また，酸の添加濃度が高くなると，ゲルの透明度は高 くなる傾向を示した。これはグロビンが酸によって部分 的に分解されて低分子化したため，巨大な塊状凝集体で はなく，線状凝集体のような網目構造が形成されやすく なったためと思われる。このような現象は，ペプシンに よるオボアルブミンの部分分解物であ観察されてお

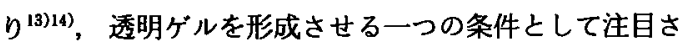
れる.

本研究では，酸としてクエン酸，酶酸，リン酸を用い たが，加水分解だけを目的とするのであれば，塩酸です 可能であった. 著者らは，グロビン溶液を塩酸で $\mathrm{pH} 2.0$ として, 90 100 ${ }^{\circ} \mathrm{C}$ で 15 分間, 加熱したところ, 本研究 における電気泳動図とほぼ同じ結果を得ている，今後， 本研究の成果を実用化する場合, 酸として塩酸を用いる ことができれば，経済性の面でも大きな進展が期待でき ると思われる。

なお，現在著者らはグロビンの酸加水分解物を調製 し，分解物のゲル形成性ならびに形成されたゲルの特性 について詳細に検討している.

\section{要約}

酸ーアセトン法によって調製されたグロビンならびに グロビン酸加水分解物のゲル形成性について检討し, 次 のような結果を得た。

（1）本法で調製したグロビンの溶解性は，pH 4.0 以 下の酸性, $\mathrm{pH} 10.0$ 以上のアルカリ性で高い値を示し， 等電点（pH 7.6 7.8）付近で最低となった.

(2) グロビンは, $\mathrm{pH} 2.0 \sim 4.0$ と $\mathrm{pH} 10.0 \sim 11.0$ の範 囲で,グロビン溄度 7\% 以上の場合，ゲルを形成した。 グロビンゲルはグロビンの等電点に近くなる程不透明と なった。
(3) グロビンのゲル形成性に対するクエン酸, 酢酸, リン酸の影響について検討した．クエン酸の場合，添加 濃度が $0.2 \mathrm{M}$ (pH 2.6) までは加熱直後にゲルを形成した が，それ以上の漕度ではゲルを形成しなかった，しかし， これを $30^{\circ} \mathrm{C} て ゙ 10$ 日間放置したところ，加熱直後のゲル よりむ，より透明で高いゲル強度を示すゲルが形成され た. しかし, $2.4 \mathrm{M}$ 添加（pH 1.1）でゲルの形成は完全に 阻害された。酶酸やリン酸の場合，ゲル形成に影響する 酸浱度 $(\mathrm{pH})$ は異なるが,クエン酸の場合とほぼ同じよ うな現象が観察された。

（4）これらの酸を用いてグロビンの加水分解を行い， 得ら机た加水分解物の SDS-PAGE を行った，その結

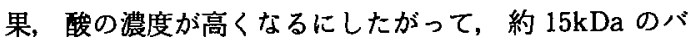
ンドは薄くなり，逆に $15 \mathrm{kDa}$ 以下のバンドか浱くなっ た. また, $15 \mathrm{kDa}$ 部分と $15 \mathrm{kDa}$ 以下の部分の量比とゲ ル強度との間の密接な関連が示唆された。

本研究の一部は, 伊藤八ム株式会社中央研究所ならび に伊藤記念財団の研究助成を受けて行われたすのであ り，深謝致します。

\section{文献}

1) WisMer-Pedersen, J. : J. Fleischwirtschaft, 60, 231 (1980).

2) Sato, Y., Hayakawa, S. and Hayakawa, M. : $J$. Food Technol., 16, 81 (1981).

3）宮口右二・境久美子・米倉政実・堤 将和：日食 工誌, 36, 720 (1989).

4) Autio, K., Lyytikainen, H., MalkK1, Y. and KanKo, S. : J. Food Sci., 50, 615 (1985).

5) TyboR, P.T., Dill, C.W. and LANDMANn, W.A. : $J$. Food Sci., 40, 155 (1975).

6）营原 潔・副島正美 : 蛋白質の定量法（第 3 版） (学会出版センター), p. 155 (1990)

7）宮口右二·米倉政実 - 堤 将和：日食工誌，39, 271 (1992).

8) LAEMmLI, U.K. : Nature, 227, 680 (1970).

9）佐藤 泰 : と畜血液利用開発推進事業報告書（と 畜血液利用委員会）p. 142 (1984).

10）北畠值文: 農化, 65, 147（1991）.

11）広瀬正明: 化学と生物, 30, 280 (1992).

12) Doi, E. and Kitabatake, N.: Food Hydrocolloids, 3, 327 (1989).

13) Kitabatake, N. and Doi, E. : Agric. Biol. Chem., 49, 2457 (1989).

14) Kitabatake, N. and Doi, E.:J. Agric. Food Chem., 36, 417 (1988).

（平成 5 年 7 月 5 日受理） 